\title{
Knowledge and attitude of candidates to gastroplasty about perioperative: randomized clinical trial
}

\author{
Conhecimento e atitude de candidatos à gastroplastia sobre perioperatório: ensaio clínico randomizado \\ Conocimiento y actitud de candidatos a la gastroplastia sobre perioperatorio: ensayo clínico aleatorizado
}

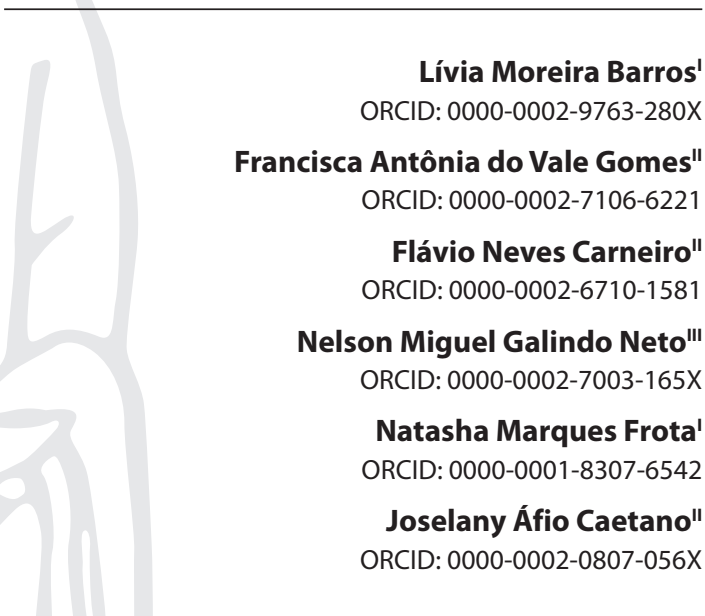

'Universidade da Integração Internacional da Lusofonia Afro-Brazileira. Redenção, Ceará, Brazil.

"Universidade Federal do Ceará. Fortaleza, Ceará, Brazil. I'Instituto Federal de Pernambuco. Pesqueira, Pernambuco, Brazil.

How to cite this article: Barros LM, Gomes FAV, Carneiro FN, Galindo Neto NM, Frota NM, Caetano JA. Knowledge and attitude of candidates to gastroplasty about perioperative: randomized clinical trial. Rev Bras Enferm. 2020;73(6):e20180869. doi: http://dx.doi.org/10.1590/0034-7167-2018-0869

\section{Corresponding author: \\ Lívia Moreira Barros \\ E-mail: livia@unilab.edu.br}

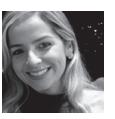

EDITOR IN CHIEF: Dulce Aparecida Barbosa ASSOCIATE EDITOR: Marcia Magro

Submission: 02-15-2019

Approval: 06-10-2020

\begin{abstract}
Objectives: to evaluate the effectiveness of educational intervention in the knowledge and attitude of candidates for gastroplasty. Methods: randomized controlled clinical trial with 56 preoperative patients (intervention $=28$; control $=28$ ). The control group received routine care from the health institution and the intervention group participated in a book-mediated educational intervention. Forms were used for clinical-epidemiological characterization and evaluation of knowledge/attitude about bariatric surgery, which were reapplied seven weeks after intervention. RBR-297fzx. Results: in the pre-test there was no significant difference between the groups $(p=0.254)$. In the post-test, the group that received verbal guidance had a mean score of $19.5( \pm 6.17)$ and the group reading the booklet averaged $31.1( \pm 2.96)$, $p=0.000$. The attitude is adequate, especially for care such as vitamin supplement intake, water intake and physical activity practice. Conclusions: the educational intervention mediated by booklet was effective in improving knowledge and attitude when compared to verbal guidance. Thus, it can be replicated during the preoperative preparation.
\end{abstract}

Descriptors: Obesity; Bariatric Surgery; Educational Technology; Knowledge; Perioperative Nursing.

\section{RESUMO}

Objetivos: avaliar efetividade de intervenção educativa no conhecimento e atitude de candidatos à gastroplastia. Métodos: ensaio clínico controlado randomizado com 56 pacientes do pré-operatório (intervenção $=28$ e controle $=28$ ). $O$ grupo controle recebeu cuidados de rotina da instituição de saúde e o grupo intervenção participou de intervenção educativa mediada por cartilha. Foram utilizados formulários para caracterização clínica-epidemiológica e avaliação do conhecimento/atitude sobre cirurgia bariátrica, os quais foram reaplicados sete semanas após intervenção. RBR-297fzx. Resultados: no pré-teste, não houve diferença significativa entre os grupos $(p=0,254)$. No pós-teste, o grupo que recebeu orientação verbal teve média de acertos de 19,5 ( $\pm 6,17)$ e o grupo que leu a cartilha acertou, em média, 31,1 $( \pm 2,96) p=0,000$. A atitude é adequada, principalmente, para cuidados como tomada do suplemento vitamínico, ingesta hídrica e prática de atividade física. Conclusões: a intervenção educativa mediada por cartilha mostrou-se eficaz na melhoria do conhecimento e manutenção de atitude positiva em relação à cirurgia bariátrica, quando comparada à orientação verbal. Assim, pode ser replicada durante o preparo pré-operatório.

Descritores: Obesidade; Cirurgia Bariátrica; Tecnologia Educacional; Conhecimento; Enfermagem Perioperatória.

\section{RESUMEN}

Objetivos: evaluar la efectividad de la intervención educativa en el conocimiento y la actitud de los candidatos a la gastroplastia. Métodos: ensayo clínico controlado aleatorizado con 56 pacientes del preoperatorio (intervención $=28$; Control=28). El grupo control recibió la atención de rutina de la institución de salud y el grupo intervención participó de intervención educativa mediada por un folleto. Se utilizaron formularios para la caracterización clínicoepidemiológica y evaluación del conocimiento/actitud sobre cirugía bariátrica, que se volvieron a aplicar siete semanas después de la intervención. RBR-297fzx. Resultados: en la pre-prueba, no hubo diferencias significativas entre los grupos $(p=0,254)$. En la prueba posterior, el grupo que recibió orientación verbal tuvo un promedio de aciertos de 19,5 ( \pm $6,17)$ y el grupo que leyó el folleto tuvo un promedio de aciertos de $31,1( \pm 2,96), p=0,000$. La actitud es adecuada, especialmente para los cuidados como tomar el suplemento vitamínico, tomar agua y practicar actividad física. Conclusiones: la intervención educativa mediada por un folleto demostró ser efectiva para mejorar el conocimiento y mantener una actitud positiva hacia la cirugía bariátrica, en comparación con la orientación verbal. Por lo tanto, se puede replicar durante la preparación preoperatoria.

Descriptores: Obesidad; Cirugía Bariátrica; Tecnología Educacional; Conocimiento; Enfermería Perioperatoria. 


\section{INTRODUCTION}

Bariatric surgery is considered the best option for patients at high risk of morbidity and mortality who do not present weight loss with conventional treatments and suffer from complications of obesity ${ }^{(1)}$. However, for its performance, preoperative preparation is necessary, in which the patient must receive information concerning the surgical procedure ${ }^{(2)}$.

Surgical intervention improves the quality of life and self-esteem, however, it causes physiological changes that must be clarified to candidates for surgery, and also offer risks and complications. These individuals must be aware of the perioperative phases and their role as active agents in the treatment and adherence to the recommendations received for therapeutic success ${ }^{(3)}$.

In the preoperative period, it is crucial to develop health education proposals, including the use of educational technologies, to guide bariatric surgery candidates to disseminate and expand knowledge about the main adaptations, benefits, risks, and challenges. The information included in educational interventions should not be limited to the most popular topics such as physical health, complications, and diet, but should also include psychosocial preparation and lifestyle changes ${ }^{(4-5)}$.

To meet the educational needs of this public, the technological resource created and validated, entitled "Bariatric surgery: care for a healthy life", stands out, which guides and encourages adherence to care in the perioperative period ${ }^{(6)}$. In a previous study, it was shown to be suitable for use by health professionals with candidates for bariatric surgery ${ }^{(6)}$.

Given the above, the following question came up: is the educational booklet more effective for improving the knowledge and attitude of patients in the preoperative period compared to the verbal guidance provided in the service routine?

\section{OBJECTIVES}

To assess the effectiveness of an educational intervention on the knowledge and attitude of candidates for bariatric surgery.

\section{METHODS}

\section{Ethical aspects}

The study was approved by the Research Ethics Committee of the Universidade Federal do Ceará and in the Brazilian Clinical Trials Records (RBR-297fzx).

\section{Study design, setting and period}

Controlled Randomized Clinical Trial (RCT) carried out from June to August 2017 at a reference institution for bariatric surgery in the State of Ceará. In this institution, the perioperative period encompasses three moments: pre-operative (mediate and immediate), trans-operative and postoperative (immediate, mediate, and late). It starts at the first consultation with the surgeon and lasts throughout the patient's life in the follow-up consultations of the late postoperative period. Thus, the follow-up of the present study occurred in the preoperative period.

\section{Participants}

The target population was composed of patients in the mediate preoperative period. Inclusion criteria were age over 18 years; be enrolled in the obesity program of the institution under study and be literate. The exclusion criterion was to use the intragastric balloon.

The exclusion criteria were: gastroplasty; placement of the intragastric balloon; and unsuccessful telephone contact after at least 10 attempts, which included calls identified as out of the area, disconnected phone or not answered.

The sample calculation was achieved using a $95 \%$ confidence coefficient $(Z a=1.96), 80 \%$ power $(Z \beta=0.84), p=10 \%$ and $d=25 \%$. A sample number of 27 patients was established for the control group (CG) and 27 patients for the intervention group (IG). Considering a $20 \%$ of losses in the follow-up, it was decided to invite the 66 eligible patients, equally distributed between CG and IG to minimize the percentage of losses during the follow-up and optimize the statistical interpretation between the data.

After the beginning of the data collection, there was a sample loss in both groups, associated with the placement of the intragastric balloon and leave for the bariatric surgery, which resulted in a sample of 56 participants (intervention=28 and control=28).

The process of including patients in the groups took place through randomization using the Research Randomizer software (www.randomizer.org). For this, the list of patients waiting for bariatric surgery was obtained from nursing management. All participants on the list were orderly numbered and then submitted to the randomization process, with 1:1 allocation in CG and Gl.

The allocation concealment was enabled from the moment of randomization and this process was carried out by the support researcher. The two lists, one with the participants of the CG and the other with the participants of the IG, were placed in thick envelopes and delivered to the main researcher. Through data collection, the researchers performed both strategies (interview and physical examination) with the groups and it was not revealed whether it was intervention or control. Thus, only the main researcher knew about the difference between patients in the groups.

The moment of the initial collection (baseline) and the implementation of the educational intervention with the IG were made exclusively by the main researcher. The follow-up of the data collected through the face-to-face and telephone meetings was carried out by two other properly trained support researchers, who did not join in the moment of randomization.

\section{Data Collection Instruments}

The instrument, developed and validated by the research group of nursing interventions in the care of adults in critical situations at the Universidade Federal do Ceará (UFC), was divided into two parts: sociodemographic characterization and assessment of knowledge and attitude about bariatric surgery. The validation of the instrument was done by three professors from the UFC nursing course who had expertise in validating instruments and publishing on educational technologies.

This instrument was developed based on the educational booklet content, the integrative review on bariatric surgery, 
and perioperative care. Overall, it encompassed 43 questions, of which 35 were about knowledge and eight about attitude, all with True or False answers. Of the questions regarding knowledge, six included general aspects of bariatric and preoperative surgery; 11 referred to postoperative hospitalization; 11 to the home postoperative period and seven to the late postoperative period. The eight questions about attitude addressed the relevance of food, hydration, physical activity, psychological support, consultations, and postoperative care.

Suitable knowledge was defined as a total of correct answers equal to or greater than $70 \%$. The attitude was defined as suitable when the individual said it was "necessary" or "very necessary" in $70 \%$ of the guidelines on care in the postoperative period of bariatric surgery; and an unsuitable attitude was when the individual indicated that it was "little necessary", "unnecessary" or answered "not having an opinion" in less than $70 \%$ of the proposed actions.

\section{Study protocol}

The baseline moment (M0) took place at the institution's outpatient clinic, with the CG and IG patients, who did not know which group they belonged to, through interviews and filling out the instruments, taking approximately 20 minutes for each participant, individually.

After M0, the CG received routine care from the institution's multi-professional team, with verbal guidance during consultations and monthly lectures with surgeons and psychologists on bariatric surgery, with a focus on surgical techniques and weight loss. With the CG, a meeting was scheduled to filling out the knowledge and attitude instrument again, seven weeks after doing it for the first (M0), so that this procedure had a time interval similar to that done in the IG.

The IG, in addition to the same routine care as the aforementioned multi-professional team of the institution, at the moment 1(M1), underwent an educational intervention based on the collective reading of the booklet entitled "Bariatric surgery: care for a healthy life" on days and times scheduled with all group participants during their mediate preoperative. There was a need to schedule four meetings since the contents of the booklet encompasse the entire perioperative process of bariatric surgery. The first three meetings were weekly and sequential, with information on the preoperative, transoperative and postoperative phases, consecutively. The last meeting, called moment 2 (M2), for filling out the instrument again, was scheduled for 30 days after the end of reading the booklet. Thus, there was a seven-week interval between the first measurement/application of the instrument in $\mathrm{M} 0$ and the second application, in M2.

The total reading time of the booklet is 20 minutes, on average. As the content is very broad, the meetings were distributed according to the themes of the perioperative phases for better understanding and assimilation of information. Each participant took, on average, five to eight minutes to read the selected chapter. The process of a collective reading of the booklet took place in the auditorium of the reference hospital, with the participants seated in the chairs lined up and the researcher in front of everyone, leading the reading and clarifying any doubts that came up in each meeting.

\section{Analysis of results and statistics}

The collected data were entered into Excel. Next, the SPSS Statistics software, version 24 , was used. The level of significance was established at $5 \%$ and the confidence interval was 95\%. From the Kolmogorov-Smirnov test, it was verified that the data did not follow the normal distribution. The knowledge test data were submitted to the Mann-Whitney test and the attitude data were analyzed using Pearson's Chi-square.

\section{RESULTS}

Participants were 56 patients in the preoperative period of bariatric surgery. Figure 1 illustrates the allocation of subjects in the study.

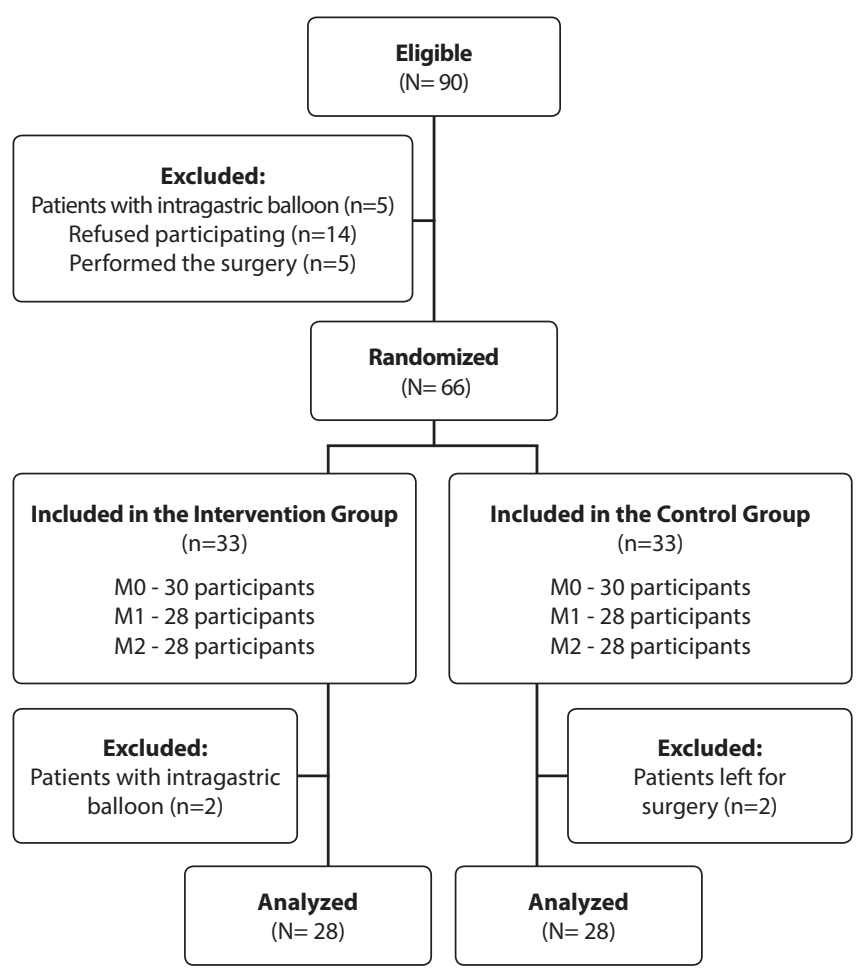

Note: MO - Baseline moment; M1 - Moment 1; M2 - Moment 2.

Figure 1 - CONSORT diagram, Fortaleza, Ceará, Brazil, 2017

The frequency of women in the control group was $83.3 \%$ (25) and $96.7 \%$ (29) in the intervention group. The mean age was $38.77 \pm 9.18$ years in the control group, with a variance of 19 to 63 years and a median of 37 years. In the intervention group, the mean age was $41.23 \pm 9.74$ years, with a variance of 21 to 65 years and a median of 40.5 years. Regarding the education, there was a predominance of 9 to 11 years among participants in the CG (63.3\%-19) and IG (53.3\%-16).

Tables 1 to 4 present information about knowledge, with a comparison of the correct answers of each group at each moment of the perioperative period and a description of the theoretical content of each question.

The only questions with a low proportion of correct answers were related to family support (in the CG - $60.7 \%$ ) and the same preparation time before surgery for all patients (42.9\% of correct answers in both groups). However, in the second moment, all items had a frequency 
of correct answers greater than 75\% in the CG and IG, except in the question of preparation time, in which the CG remained with $42.9 \%$ of correct answers, compared to $75 \%$ of the IG ( $p=0.035)$ and questions about the importance of family support and the need to try conventional treatments to lose weight before choosing bariatric surgery, both with $71.4 \%$ correct answers (Table 1).
Table 2 shows that questions about the benefits of walking and compression stockings for preventing thrombosis, and about lung improving with breathing exercises, were the only ones with correct answers above $70 \%$ in $\mathrm{M} 0$. After the intervention, all patients in the IG demonstrated suitable knowledge about the issues related to hospitalization and care in the hospital postoperative.

Table 1 - Comparison of correct answers to questions on bariatric and preoperative surgery between groups ( $\mathrm{n}=56$ ), Fortaleza, Ceará, Brazil, 2017

\begin{tabular}{|c|c|c|c|c|c|c|}
\hline \multirow[b]{2}{*}{$\begin{array}{l}\text { Questions: } \\
\text { Surgery and preoperative }\end{array}$} & \multicolumn{2}{|c|}{ Mo } & \multicolumn{4}{|c|}{ M2 } \\
\hline & $\begin{array}{c}\text { CG } \\
\text { Correct } \\
\text { answer } \\
\% \text { (n) }\end{array}$ & $\begin{array}{c}\text { IG } \\
\text { Correct } \\
\text { answer } \\
\% \text { (n) }\end{array}$ & pt & $\begin{array}{c}\text { CG } \\
\text { Correct } \\
\text { answer } \\
\%(n)\end{array}$ & $\begin{array}{c}\text { IG } \\
\text { Correct } \\
\text { answer } \\
\% \text { (n) }\end{array}$ & $p t$ \\
\hline 1. Benefits of surgery. & $28(93.3)$ & $30(100)$ & 0.154 & $28(100.0)$ & $28(100)$ & 1 \\
\hline 2. Family support for surgery. & $18(60.0)$ & $23(76.7)$ & 0.169 & $20(71.4)$ & $24(85.7)$ & 0.197 \\
\hline 3. Attempt to lose weight with conventional treatments. & $25(83.3)$ & $28(93.3)$ & 0.232 & $20(71.4)$ & $26(92.9)$ & 0.038 \\
\hline 4. Preoperative objective (clinical assessment and education). & $26(86.7)$ & $24(80.0)$ & 0.492 & $23(82.1)$ & $28(100)$ & 0.020 \\
\hline 5. Smoking and alcohol cessation. & $29(96.7)$ & $29(96.7)$ & 1 & $28(100)$ & $28(100)$ & 1 \\
\hline 6. Equal preparation time before surgery for all patients. & $14(46.7)$ & $13(43.3)$ & 0.797 & $12(42.9)$ & $21(75.0)$ & 0.015 \\
\hline
\end{tabular}

Note: MO - Baseline moment; M2 - Moment 2; CG - Control Group; IG - Intervention Group; + Mann Whitney test for comparison between groups.

Table 2 - Comparison of correct answers on questions about postoperative hospitalization between groups ( $\mathrm{n}=56$ ), Fortaleza, Ceará, Brazil, 2017

\begin{tabular}{|c|c|c|c|c|c|c|}
\hline \multirow[b]{2}{*}{$\begin{array}{l}\text { Questions: } \\
\text { Hospitalization and hospital postoperative }\end{array}$} & \multicolumn{2}{|c|}{ Mo } & \multicolumn{4}{|c|}{ M2 } \\
\hline & $\begin{array}{c}\text { CG } \\
\text { Correct } \\
\text { answer } \\
\% \text { (n) }\end{array}$ & $\begin{array}{c}\text { IG } \\
\text { Correct } \\
\text { answer } \\
\%(n)\end{array}$ & $p \dagger$ & $\begin{array}{c}\text { CG } \\
\text { Correct } \\
\text { answer } \\
\% \text { (n) }\end{array}$ & $\begin{array}{c}\text { IG } \\
\text { Correct } \\
\text { answer } \\
\%(\mathbf{n})\end{array}$ & $p \dagger$ \\
\hline 7. Fasting before surgery. & $16(53.3)$ & $20(66.7)$ & 0.296 & $17(60.7)$ & $28(100.0)$ & 0.000 \\
\hline 8. Medication to prevent blood clots. & $14(46.7)$ & $18(60.0)$ & 0.305 & $16(57.1)$ & $28(100.0)$ & 0.000 \\
\hline 9. Transfer to the room immediately after surgery. & $9(30.0)$ & $15(50.0)$ & 0.117 & $11(39.3)$ & $22(78.6)$ & 0.003 \\
\hline 10. Risks and complications related to surgery. & $16(53.3)$ & $18(60.0)$ & 0.605 & $16(57.1)$ & $24(85.7)$ & 0.019 \\
\hline 11. Possible fall out of stitches and staples, leading to infection. & $6(20.0)$ & $8(26.7)$ & 0.545 & $6(21.4)$ & $23(82.1)$ & 0.000 \\
\hline 12. Need for reoperation after complications. & $9(30.0)$ & $16(53.3)$ & 0.069 & $16(57.1)$ & $24(85.7)$ & 0.019 \\
\hline 13. Bed rest throughout hospitalization. & $11(36.7)$ & $14(46.7)$ & 0.436 & $8(28.6)$ & $26(92.9)$ & 0.000 \\
\hline 14. Beginning of the liquid diet without the doctor's consent. & $17(56.7)$ & $20(66.7)$ & 0.430 & $14(50.0)$ & $25(89.3)$ & 0.002 \\
\hline 15. Benefits of walking and compression stockings. & $22(73.3)$ & $19(63.3)$ & 0.409 & $20(71.4)$ & $28(100.0)$ & 0.317 \\
\hline 16. Lung improvement with breathing exercises. & $28(93.3)$ & $28(93.3)$ & 1.000 & $27(96.4)$ & $28(100.0)$ & 0.000 \\
\hline 17. Edema, heat, and redness in the surgical wound. & $5(16.7)$ & $12(40.0)$ & 0.047 & $4(14.3)$ & $20(71.4)$ & 0.000 \\
\hline
\end{tabular}

Note: MO - Baseline moment; M2 - Moment 2; CG - Control Group; IG - Intervention Group; + Mann Whitney test for comparison between groups.

Table 3 - Comparison of correct answers on questions about home postoperative between groups ( $n=56$ ), Fortaleza, Ceará, Brazil, 2017

\begin{tabular}{|c|c|c|c|c|c|c|}
\hline \multirow[b]{2}{*}{$\begin{array}{l}\text { Questions: } \\
\text { Postoperative at home }\end{array}$} & \multicolumn{2}{|c|}{ Mo } & \multicolumn{4}{|c|}{ M2 } \\
\hline & $\begin{array}{c}\text { CG } \\
\text { Correct } \\
\text { answer } \\
\%(n)\end{array}$ & $\begin{array}{c}\text { IG } \\
\text { Correct } \\
\text { answer } \\
\%(\mathbf{n})\end{array}$ & $p+$ & $\begin{array}{c}\text { CG } \\
\text { Correct } \\
\text { answer } \\
\% \text { (n) }\end{array}$ & $\begin{array}{c}\text { IG } \\
\text { Correct } \\
\text { answer } \\
\% \text { (n) }\end{array}$ & $p+$ \\
\hline 18. Cleaning the surgical wound. & $15(50.0)$ & $17(56.7)$ & 0.608 & $14(50.0)$ & $27(96.4)$ & 0.000 \\
\hline 19. Progression of the diet through adaptation and correct chewing. & $17(56.7)$ & $23(76.7)$ & 0.103 & $16(57.1)$ & $27(96.4)$ & 0.000 \\
\hline 20. Regular postoperative nausea and vomiting. & $1(3.3)$ & $2(6.7)$ & 0.557 & $1(3.6)$ & $13(46.4)$ & 0.000 \\
\hline 21. Restriction of sweets, soda, and high-calorie drinks in the first six months. & $27(90.0)$ & $27(90.0)$ & 1.000 & $25(89.3)$ & $27(96.4)$ & 0.304 \\
\hline 22. Drinking water only when you feel thirsty. & $5(16.7)$ & $4(13.3)$ & 0.720 & $4(14.3)$ & $12(42.9)$ & 0.190 \\
\hline 23. Daily intake of vitamin supplements. & $22(73.3)$ & $21(70.0)$ & 0.776 & $21(75.0)$ & $27(96.4)$ & 0.023 \\
\hline 24. Pain when swallowing, vomiting or esophageal stricture if chewing is not done properly. & $22(73.3)$ & $22(73.3)$ & 1.000 & $20(71.4)$ & $24(85.7)$ & 0.197 \\
\hline 25. Brushing teeth after vomiting. & $3(10.0)$ & $5(16.7)$ & 0.451 & $4(14.3)$ & $26(92.9)$ & 0.000 \\
\hline 26. Chance of psychological disorders or compulsions in the postoperative period. & $12(40.0)$ & $16(53.3)$ & 0.305 & $8(28.6)$ & $25(89.3)$ & 0.000 \\
\hline 27. Return to consultations only in the first year after surgery. & $14(46.7)$ & $23(76.7)$ & 0.018 & $10(35.7)$ & $24(85.7)$ & 0.000 \\
\hline 28. Search for health professionals if doubts or health problems. & $23(76.7)$ & $27(90.0)$ & 0.169 & $24(85.7)$ & $27(96.4)$ & 0.164 \\
\hline 29. Greater weight loss (first six months) by controlled eating and physical activity. & $26(86.7)$ & $19(63.3)$ & 0.038 & $23(82.1)$ & $28(100.0)$ & 0.020 \\
\hline 30. Maintenance of weight loss. & $19(63.3)$ & $19(63.3)$ & 1.000 & $23(82.1)$ & $28(100.0)$ & 0.020 \\
\hline 31. Changes in smell, taste, and feces odor. & $13(43.3)$ & $12(40.0)$ & 0.795 & $11(39.3)$ & $26(92.9)$ & 0.000 \\
\hline $\begin{array}{l}\text { 32. Discontinuing of medications, after the improvement of clinical conditions without medical } \\
\text { permission. }\end{array}$ & $7(23.3)$ & 5 (16.7) & 0.522 & 5 (17.9) & $16(57.1)$ & 0.003 \\
\hline 33. Dumping syndrome (concept and symptoms). & $15(50.0)$ & $13(43.3)$ & 0.608 & $14(50.0)$ & $27(96.4)$ & 0.000 \\
\hline 34. Alcohol consumption after three months and effects of alcohol. & $21(70.0)$ & $24(80.0)$ & 0.375 & $20(71.4)$ & $28(100.0)$ & 0.002 \\
\hline 35. Hair loss, brittle nails, and dry skin due to nutritional deficiencies. & $21(70.0)$ & $18(60.0)$ & 0.421 & $18(64.3)$ & $27(96.4)$ & 0.003 \\
\hline
\end{tabular}

Note: M0 - Baseline moment; M2 - Moment 2; CG - Control Group; IG - Intervention Group; + Mann Whitney test for comparison between groups. 
Table 4 - The comparison of the attitude about follow-up care in the perioperative period of bariatric surgery between groups [n=60 (M0); $n=56(M 2)$, Fortaleza, Ceará, Brazil, 2017

\begin{tabular}{|c|c|c|c|c|c|c|}
\hline \multirow[b]{2}{*}{ Attitude } & \multicolumn{2}{|c|}{ Mo } & \multicolumn{4}{|c|}{ M2 } \\
\hline & $\begin{array}{l}\text { CG } \\
\%(n)\end{array}$ & $\begin{array}{l}\text { IG } \\
\% \text { (n) }\end{array}$ & $p+$ & $\begin{array}{l}\text { CG } \\
\%(n)\end{array}$ & $\begin{array}{l}\text { IG } \\
\% \text { (n) }\end{array}$ & $p \dagger$ \\
\hline Follow the nutritionist's guidelines & & & & & & \\
\hline Suitable & $30(100)$ & $29(96.7)$ & 0.313 & $28(93.3)$ & $27(90.0)$ & 0.313 \\
\hline Take the vitamin supplement daily & & & & & & \\
\hline Suitable & $26(86.7)$ & $24(80.0)$ & 0.488 & $26(86.7)$ & $26(86.7)$ & - \\
\hline $\begin{array}{l}\text { Drink at least two liters of water a day } \\
\text { Suitable }\end{array}$ & $30(100)$ & $29(96.7)$ & 0.313 & $28(93.3)$ & $28(93.3)$ & - \\
\hline $\begin{array}{l}\text { Chew food before swallowing } \\
\text { Suitable }\end{array}$ & $30(100)$ & $29(96.7)$ & 0.313 & $28(93.3)$ & $28(93.3)$ & - \\
\hline $\begin{array}{l}\text { Physical activities practice } \\
\text { Suitable }\end{array}$ & $29(96.7)$ & $29(96.7)$ & 1.000 & $28(93.3)$ & $28(93.3)$ & - \\
\hline $\begin{array}{l}\text { Follow-up with a psychologist } \\
\text { Suitable }\end{array}$ & $29(96.7)$ & $30(100)$ & 0.313 & $28(93.3)$ & $28(93.3)$ & - \\
\hline $\begin{array}{l}\text { Return to postoperative consultations } \\
\text { Suitable }\end{array}$ & $30(100)$ & $29(96.7)$ & 0.321 & $28(93.3)$ & $28(93.3)$ & - \\
\hline
\end{tabular}

Regarding care at home in the postoperative period, in both groups, the correct answers were low $(<70 \%)$ in questions about the cleaning of the surgical wound, vomiting and nausea, fluid intake, tooth brushing and the occurrence of psychological disorders. For these questions, there were no statistically significant differences between the participants of the CG in $M 2$, while the IG showed an increase in the number of correct answers, with a frequency higher than $85 \%$ and statistically significant, except for the questions about regular vomiting and nausea $(p=0.001)$ and water intake, even if not thirst $(p=0.039)$ (Table 3$)$.

The questions about the late postoperative period with correct answers above $70 \%$, in $\mathrm{M} 0$ were related to weight loss due to controlled eating and physical activity and effects of alcohol consumption. In the second assessment (M2), there was an improvement in knowledge for the IG in all questions, except concerning the discontinuing of medication, however, with statistical significance $(p=0.002)$ (Table 3$)$.

In M0, the average of correct answers was $19.2( \pm 5.85)$ for the CG and 21.07 ( \pm 5.82 ) for IG, with a p-value of 0.254 (similar knowledge in the baseline). In M2, the CG had an average of 19.5 ( \pm 6.17 ) and the IG of 31.1 ( \pm 2.96 ), $p=0.000$. Besides, of the 35 questions about knowledge, the CG showed an increase in correct answers in 13 post-test questions, only one with statistical significance, while the IG increased up to 31 correct answers, with statistical significance in 17 of them.

The comparison of the attitude of both groups in the pre and post-test moments is shown in table 4.

In Table 4, it is possible to observe that in $\mathrm{M} 0$ and $\mathrm{M} 2$, patients showed a positive attitude to follow the care to change their lifestyle habits. Most study participants consider it important to follow-up care in the postoperative period to improve the quality of life and health status.

For the CG, correctly following postoperative care is associated with improved quality of life ( $M 0=40 \% ; M 2=43.3 \%)$. For the IG, improving quality of life was more frequent in $\mathrm{M0}(53.3 \%)$ and improving health status and comorbidities (53.3\%) in M2.

\section{DISCUSSION}

Educational strategies applying technologies printed with organized illustrations and information before bariatric surgery can promote self-care attitudes. They represent the opportunity to solve doubts and help patients deal with their expectations concerning the surgical procedure and the experience of the postoperative period.

In the post-test, all participants demonstrated satisfactory knowledge about the main benefits of bariatric surgery. It is relevant to know the benefits of the surgical procedure, such as weight loss and improved metabolic parameters, to propose actions that avoid complications, promote self-care, and improve quality of life ${ }^{(7)}$. A qualitative study was carried out in Pennsylvania to identify the perceptions of postoperative patients about the guidance received by the multi-professional team, and showed that the participants consider relevant the information on types of surgery, their risks/benefits and weight loss ${ }^{(8)}$.

In this study, patients revealed that they consider the preoperative preparation time similar for all individuals, which can be observed in the total of correct answers, below 50\%. In the post-test, only the intervention group achieved improvement in knowledge $(42.9 \%$ to $75 \%, p=0.035)$ in this regard. Often, the required behavioral changes and preoperative assessments cause delays in the process, intensifying signs of dissatisfaction for people who are in a hurry to get it done ${ }^{(9)}$.

In the present study, a low percentage of correct answers (less than 50\%) was found in M0 regarding the prevention of Deep Venous Thrombosis (DVT) and the need for care such as early walking and the use of compression stockings in the postoperative period. A study carried out in the United States identified that patients with less education are more likely to develop complications such as DVT ${ }^{(10)}$. As a prophylactic measure for venous thrombosis, patients can receive low molecular weight heparin and medium compression stockings above the knee in the night before surgery, with continuous use for 10 postoperative days; using compression devices during the surgical procedure; perform motor exercises or slow walks in the immediate postoperative period $^{(11)}$

Regarding the breathing exercises, both groups had correct answers greater than $90 \%$, with no significant difference between the moments of the collection. Morbidly obese patients are at increased risk of hypoxemia in the postoperative period, 
which can cause a higher incidence of postoperative pulmonary complications, increase the length of hospital stay and reflect higher health costs $^{(12)}$.

As for the possible fall out of the stomach stitches and the need for reoperation, there was an improvement in knowledge (M2-M0) only among patients who had access to the booklet, with a p-value of 0.000 and 0.003 , respectively. The detailed assessment of the surgical risks for each patient is important for the patient's informed decision-making regarding the surgical treatment of obesity, besides guiding the multidisciplinary team to the choice of the specific intervention that improves the results in the preparation and after surgery ${ }^{(13)}$.

In the United States, an intervention study using printed materials with $3 \mathrm{D}$ animations to guide 19 adults about the risks of bariatric surgery showed that the participants were able to infer key elements to prevent complications, such as properly chewing food and correctly follow the liquid diet to avoid surgical ruptures ${ }^{(14)}$.

During preoperative preparation, information related to nutrition should be highlighted, such as compliance with the diet, hydration, and food satisfaction. Sparkling drinks are also contraindicated, as they cause dilation ${ }^{(15)}$. The benefits of following nutritional guidelines are associated with reducing the incidence of slow weight loss, plateau effect, weight gain, dehydration, pain, discomfort, indigestion, vomiting and dumping syndrome. However, the ability to make changes in the diet depends on environmental factors (the house and kitchen assembly and the availability of easy access to buy food); financial (ability to afford the costs related to the acquisition of protein, vitamins, fresh fruits and vegetables); family and psychological support ${ }^{(16)}$.

In Israel, a randomized clinical trial with 128 candidates for bariatric surgery applied online educational intervention on pre- and post-surgery dietary guidelines; food supplement and nutritional strategies to maintain long-term weight loss. The intervention patients had a better performance in the knowledge test about nutritional aspects and lower scores of anxiety, compared to the control group ${ }^{(17)}$.

An issue that causes concern is the patients' belief about regular nausea and vomiting in the postoperative period. Bariatric surgery restricts the amount of food that an individual can consume ${ }^{(18)}$. Thus, if the patient does not respect the signs that the body shows it is full during meals, the probability of vomiting is greater.

It is known that the frequent vomiting, with immediate teeth brushing, can increase mineral loss due to the loss of calcium in the tooth enamel, leading to tooth hypersensitivity, which may have an impact on the patient's quality of life ${ }^{(19)}$. Despite the bad feeling due to the unpleasant taste in the mouth, it is recommended that patients wait 20 to 30 minutes to brush their teeth.

In the postoperative period, the patient may experience episodes of depression, shopping, drink and eating compulsion or other psychological disorders, therefore the importance of advising patients preoperatively about the occurrence of these events.

Both eating behavior and depression in the post-surgical period are associated with less weight loss ${ }^{(20)}$. In Portugal, a crosssectional study showed the association between weight gain after surgery and episodes of compulsive food intake, concerns about body image and depressive symptoms ${ }^{(21)}$, which warns of the need for professional support in the postoperative period.
In Germany, a randomized clinical trial was conducted with 117 patients to assess the effectiveness of psychoeducational intervention after bariatric surgery. The topics covered were: how to deal with binge eating, pinching, society and feelings, in addition to body image, perfectionism, self-esteem and self-nutrition. The results showed that the group that participated in the program for two years had better self-efficacy and reduced scores of depression severity ${ }^{(22)}$.

It is important to prepare the patient for physical and behavioral changes that may occur after surgery. In the postoperative period, changes in the taste and smell of the food are normal; an increase in the number of daily bowel movements with feces and gases with a strong-smelling odor; increased sweat and abrasions in areas where there is excess skin.

As fats are poorly absorbed, feces are more frequent and have a strong-smelling odor. Complaints such as cold intolerance, hair loss, fatigue and dry skin occur due to the decrease in the basal metabolic rate ${ }^{(23)}$. Hypometabolism is common during the first six months after bariatric surgery and these effects tend to decrease as weight loss stabilizes ${ }^{(24)}$.

As for the knowledge of one of the most common complications, which is the dumping syndrome, there was a difference between the groups, and the variation of correct answers was from $53.6 \%$ $(\mathrm{M} 0)$ to $50 \%$ in the control group $(\mathrm{p}=1)$, and from $46.4 \%$ to $96.4 \%$ in the intervention group $(p=0.000)$. This syndrome is characterized by vasomotor and gastrointestinal symptoms caused by rapid gastric emptying after eating or the sudden exposure of the small intestine to nutrients $s^{(25-26)}$.

In this study, both in $\mathrm{M} 0$ and $\mathrm{M} 2$, a positive attitude was observed given the need for obedience to care in the postoperative period to achieve positive and lasting results. The absence of variation in the verification of the candidates' attitude is a relevant finding and demonstrates that the participants consider it necessary to follow up with the multi-professional team.

This reveals that the participants know the theme addressed, arising from the guidelines received at the institution and from living with other postoperative patients during monthly meetings. More and more, the population has been searching for information about bariatric surgery on the internet and with friends, to understand more about the procedure and the necessary care ${ }^{(6)}$.

Educating people should not be interpreted as a way of adding knowledge and values, but as an action centered on the problematization of daily life, on individual, family and social groups experience, and respect for cultural differences ${ }^{(27)}$. Making the patient active and engaged in the care process through health education, will enable greater individual interest in the search for knowledge about the body function and the diseases to which it is subject, reducing the morbidity and mortality rates and improving the quality of care life ${ }^{(28)}$.

\section{Study limitations}

The study limitation refers to its conduction with participants accompanied by the SUS bariatric surgery program, which represents a population with a low level of education. Thus, the results may differ from the reality of patients in the preoperative period of private health institutions, who have greater purchasing power and higher education. 


\section{Contributions to the Area}

Often, information alone is not enough to promote the necessary behavioral changes, as an informed patient does not mean a prepared patient ${ }^{(29-30)}$. However, it was possible to observe an improvement in the level of knowledge among the intervention participants. Only the information shared in educational interventions, by itself, will not change behaviors concerning the problem. Although knowledge is a necessary condition for the process of changing a specific practice or behavior, other variables, such as attitude, will have to be changed for certain risky behavior to be adjusted(31).

Regardless of the level of knowledge, patients have a positive attitude towards the necessary care in the perioperative period of bariatric surgery, and it is important to assess the follow-up of the current guidelines, given their biopsychosocial scenario.

\section{CONCLUSIONS}

The combined educational strategy (booklet and the institution routine) was effective in acquiring knowledge from candidates for bariatric surgery about the necessary care in the perioperative period, when compared to the institution's routine method for the patient guidance, which is performed verbally. Regarding attitude, during the seven-week follow-up, patients kept a positive attitude concerning the main care for bariatric surgery.

Further studies are suggested, with the application of the instrument in other scenarios for the obese in Brazil, to verify if there is a difference in the level of knowledge of patients in different cultural contexts, also the continuity of the monitoring of patients who participated in the IG, to investigate the result of educational intervention in the acquisition of knowledge over time.

\section{REFERENCES}

1. Swash C. Bariatric surgery and implications for stoma care. Br J Nurs. 2016;25(5):S22, S24-7. doi: 10.12968/bjon.2016.25.5.S22

2. Esquivel CM, Garcia M, Armando L, Ortiz G, Lascano FM, Foscarini JM. Laparoscopic Sleeve Gastrectomy Resolves NAFLD: Another Formal Indication for Bariatric Surgery? Obes Surg. 2018. doi: 10.1007/s11695-018-3466-7

3. Gesquiere I, Augustijns P, Lannoo M, Matthys C, Van der Schueren B, Foulon V. Barriers in the Approach of Obese Patients Undergoing Bariatric Surgery in Flemish Hospitals. Obes Surg. 2015; 25(11):2153-8. doi: 10.1007/s11695-015-1680-0

4. Owers C, Halliday V, Saradjian A, Ackroyd R. Designing pre-bariatric surgery education: the value of Patients' experiences. J Diabetes Nurs [Internet] 2017 [cited 2018 Jun 29];21(4):119-25. Available from: http://eprints.whiterose.ac.uk/117426/

5. Fencl JL, Walsh A, Vocke D. The bariatric patient: an overview of perioperative care. AORN J. 2015;102(2):116-31. doi: 10.1016/j.aorn.2015.05.007

6. Barros LM, Brandao MGSA, Barbosa AO, Nascimento LA, Ximenes LB, Caetano, JA. Use of group discussion as an educational strategy in nursing appointments on bariatric surgery. J Nurs Educ Pract. 2018; 8:36-44. doi: 10.5430/jnep.v8n12p36

7. Barros LM, Frota NM, Moreira RAN, Araújo TM, Caetano JA. Assessment of bariatric surgery results. Rev Gaúcha Enferm. 2015;36(1):21-7. doi: 10.1590/1983-1447.2015.01.4769

8. Groller KD, Teel C, Stegenga KH, El Chaar M. Patient perspectives about bariatric surgery unveil experiences, education, satisfaction, and recommendations for improvement. Surg Obes Relat Dis. 2018;14(6):785-96. doi: 10.1016/j.soard.2018.02.016.

9. Cardoso CMC, Costa ALRC. The burden of living with obesity. Rev Min Enferm. 2013;17(4):806-14. doi: 10.5935/1415-2762.20130059

10. Mahoney ST, Tawfik-Sexton D, Strassle PD, Farrell TM, Duke MC. Effects of Education and Health Literacy on Postoperative Hospital Visits in Bariatric Surgery. J Laparoendosc Adv Surg Tech A. 2018; 28(9):1 100-1104. doi: 10.1089/lap.2018.0093

11. Sinha A, Jayaraman L, Punhani D, Chowbey P. Enhanced Recovery after Bariatric Surgery in the Severely Obese, Morbidly Obese, Super-Morbidly Obese and Super-Super Morbidly Obese Using Evidence-Based Clinical Pathways: a Comparative Study. Obes Surg. 2017;27(3):560-568. doi: 10.1007/s11695-016-2366-y

12. Nardi AT, Real AA, Santos TD, Rocha RO, Lenzi TL. Efeito do treinamento muscular inspiratório em pacientes submetidos à cirurgia bariátrica: uma revisão sistemática. Fisioter Pesqui. 2016;23(4):448-57. doi: 10.1590/1809-2950/16901723042016

13. Ghoneim MM, O'Hara MW. Depression and postoperative complications: An overview Visceral and general surgery. BMC Surg. $2016 ; 16: 5$. doi: 10.1186/s12893-016-0120-y

14. Siddle J, Lindsay A, Ferreira JF, Porteous J, Read J, Charles F, et al. Visualization of patient behavior from natural language recommendations. In Proceedings of K-CAP 2017: Knowledge Capture Conference (K-CAP 2017). ACM, New York, NY, USA, 5 pages. doi: 10.1145/3148011.3148036

15. Zyger LT, Zanardo VPS, Tomicki C. Perfil nutricional e estilo de vida de pacientes pré e pós-cirurgia bariátrica. Scientia Medica. 2016;26(3):23707. doi: 10.15448/1980-6108.2016.3.23707

16. Leahy CR, Luning A. Review of nutritional guidelines for patients undergoing bariatric surgery. AORN J. 2015;102(2):153-60. doi: 10.1016/j. aorn.2015.05.017

17. Sherf-Dagan S, Hod K, Mardy-Tilbor L, Gliksman S, Ben-Porat T, Sakran N, et al. The Effect of Pre-Surgery Information Online Lecture on Nutrition Knowledge and Anxiety Among Bariatric Surgery Candidates. Obes Surg. 2018; 28(7):1876-1885. doi: 10.1007/s11695-018-3134-y

18. Cassin SE, Sockalingam S, Du C, Wnuk S, Hawa R, Parikh SV. A pilot randomized controlled trial of telephone-based cognitive behavioural therapy for preoperative bariatric surgery patients. Behav Res Ther. 2016; 80:17-22. doi: 10.1016/j.brat.2016.03.001 
19. Lussi A, Carvalho TS. Erosive tooth wear: a multifactorial condition of growing concern and increasing knowledge. Monogr Oral Sci. 2014; 25:1-15. doi: $10.1159 / 000360380$

20. Meany G, Conceição E, Mitchell JE. Binge eating, binge eating disorder and loss of control eating: effects on weight outcomes after bariatric surgery. Eur Eat Disord Rev. 2014;22(2):87-91. doi: 10.1002/erv.2273

21. Ramalho S, Bastos AP, Silva C, Vaz AR, Brandão I, Machado PP, et al. Excessive skin and sexual function: relationship with psychological variables and weight regain in women after bariatric surgery. Obes Surg. 2015; 25(7):1149-54. doi: 10.1007/s11695-014-1514-5

22. Wild B, Hünnemeyer K, Sauer H, Schellberg D, Müller-Stich BP, Königsrainer A, et al. Sustained effects of a psychoeducational group intervention following bariatric surgery: follow-up of the randomized controlled base study. Surg Obes Relat Dis. 2017;13(9):1612-8. doi: 10.1016/j.soard.2017.03.034

23. Vilchez López FJ, Campos Martín C, Amaya García MJ, Sánchez Vera P, Pereira Cuni JL. Very low calorie diets in clinical management of morbid obesity. Nutr Hosp. 2013;28(2):275-85. doi: 10.3305/nh.2013.28.2.6285

24. Glatt D, Sorenson T. Metabolic and bariatric surgery for obesity: a review. S D Med. [Internet] 2011 [cited 2018 Jun 29];Spec No:57-62. Available from: https://www.ncbi.nlm.nih.gov/pubmed/21721189

25. Rickers L, McSherry C. Bariatric surgery: nutritional considerations for patients. Nurs Stand. 2012;26(49):41-8. doi: 10.7748/ ns2012.08.26.49.41.c9235

26. Tack J, Deloose E. Complications of bariatric surgery: dumping syndrome, reflux and vitamin deficiencies. Best Pract Res Clin Gastroenterol. 2014;28(4):741-9. doi: 10.1016/j.bpg.2014.07.010

27. Alves GG, Aerts D. As práticas educativas em saúde e a Estratégia Saúde da Família. Ciên Saúde Coletiva. 2011;16(1):319-25. doi: 10.1590/ S1413-81232011000100034

28. Arantes RKM, Salvagioni DAJ, Araujo JP, Roecker S. Educação que produz saúde: atuação da enfermagem em grupo de hipertensos. Rev Enferm UFSM. 2015;5(2):213-23. doi: 10.5902/2179769213472

29. Berdinarelli LMM, Guedes NAC, Clos AC, Ramos JP, Chaves ACS, Vieira C. Produção do conhecimento em enfermagem acerca do empoderamento em situações crônicas de saúde. Rev Enferm UERJ. 2015;23(3):413-9. doi: 10.12957/reuerj.2015.16799

30. Martins MP, Abreu-Rodrigues M, Souza JR. The use of the internet by the patient after bariatric surgery: contributions and obstacles for the follow-up of multidisciplinary monitoring. ABCD, Arq Bras Cir Dig. 2015;28(Suppl 1):46-51. doi: 10.1590/S0102-6720201500S100014

31. Freire P. Pedagogia do oprimido. 45 Ed. São Paulo: Paz e Terra, 2005. 184 p. 